\title{
CHANGES IN THE DAILY ROUTINE AND LIFE PERCEPTIONS OF OLDER ADULTS DUE TO THE CORONAVIRUS DISEASE 2 O19 (COVID-19) PANDEMIC
}

\section{Alterações na rotina diária e percepções de vida de adultos idosos devido à pandemia de doença pelo coronavírus 2019 (COVID-19)}

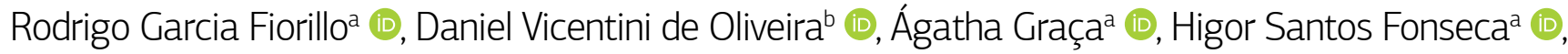 \\ Flávio Ricardo Guilhermec (i), Lenamar Fiorese ${ }^{\mathrm{b}}$ (D), José Roberto Andrade do Nascimento Júniord (D), \\ Fábio Luiz Cheche Pina ${ }^{(D)}$, Jerry Mayhew ${ }^{f}$, Matheus Amarante do Nascimento ${ }^{a}$ (i)
}

OBJECTIVE: This study aimed to analyze changes in the daily routine and life perceptions of older adults due to the coronavirus disease 2019 pandemic. METHODS: This is a cross-sectional study conducted with 338 older adults (93 men and 238 women)

$\vdash \quad$ residing in southern Brazil. An online questionnaire consisting of 20 questions was created using the Google Forms platform and was distributed to older adults (> 60 years of age) during the isolation period caused by the coronavirus disease pandemic. Data analysis was conducted through Student's-t and $\chi^{2}$ tests. RESULTS: Our results showed a significant association between social isolation and sex $(p<0.01)$, revealing that women experienced higher levels of social isolation than men. We observed that $82.21 \%$ of the older adults participating in this study reported changes in their social routines during the pandemic. CONCLUSIONS: During this period of extended social isolation, women reported more negative effects than men. KEYWORDS: aging; behavior; social isolation.

OBJETIVO: Este estudo teve como objetivo analisar as alterações perceptivas em idosos em decorrência da pandemia de COVID-19. METODOLOGIA: Estudo transversal realizado com 338 idosos (93 homens e 238 mulheres), residentes na região sul do Brasil. Um questionário online criado na plataforma Google Forms ${ }^{\circledR}$, composto por 20 questões, foi aplicado aos idosos no período de isolamento devido à pandemia do COVID-19. A análise dos dados foi realizada por meio do teste t de Student e teste do $\chi^{2}$. RESULTADOS: Encontrou-se uma associação significativa entre isolamento social e sexo ( $\left.p<0,01\right)$, revelando que as mulheres vivenciaram maior isolamento social do que os homens. Observa-se que $82,21 \%$ dos idosos relataram mudança na rotina social durante a pandemia. CONCLUSÕES: Durante esse período de isolamento social prolongado, as mulheres mostraram mais efeitos negativos do que os homens.

PALAVRAS-CHAVE: envelhecimento; comportamento; isolamento social.

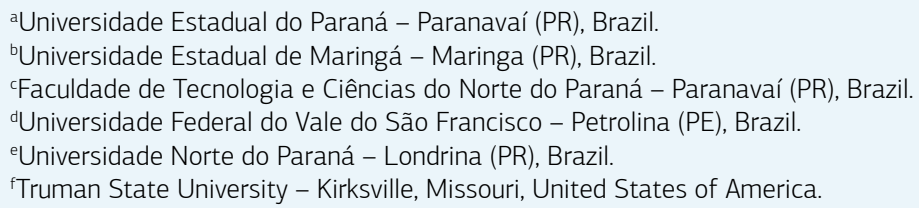

How to cite this article: Fiorillo RG, Oliveira DV, Graça A, Fonseca HS, Guilherme FR, Fiorese L, et al. Changes in the daily routine and life perceptions of older adults due to the coronavirus disease 2019 pandemic. Geriatr Gerontol Aging. 2021;15:e0210003. https://doi.org/10.5327/22447-212320212000115 https://doi.org/10.5327/Z2447-212320212000115 


\section{INTRODUCTION}

The coronavirus disease 2019 (COVID-19) is a respiratory infection that presents several symptoms such as fever, cough, fatigue, and in some cases, gastrointestinal infection. ${ }^{1}$ In severe cases, it may cause pneumonia, pulmonary edema, acute respiratory distress syndrome, and/or multiple organ failure, ${ }^{2}$ potentially leading to death.

The risk of dying from COVID-19 usually increases with age, ${ }^{3}$ and in Brazil, the first death among older adults was registered on March 17, 2020. ${ }^{4}$ According to recent data from the Brazilian Ministry of Health, more than $80 \%$ of all deaths in the country were of older adults (> 60 years old), most of whom had comorbidities (cardiovascular and respiratory diseases and/or diabetes). ${ }^{4}$ Due to the severity of this pandemic, government health agencies worldwide adopted several measures for ensuring isolation and social distancing, interrupting classes and closing borders, ultimately causing a financial crisis ${ }^{5}$ and negative social impact. ${ }^{6}$

Since advancing age causes progressive loss of the body's functional abilities and a decrease in physical capacities, maintaining an active lifestyle can reduce risks inherent to physical inactivity. Many factors can influence physical inactivity: sex, socioeconomic status, marital status, schooling, obesity, smoking habits, alcoholism, and self-perceived health, ${ }^{7,8}$ as well as environmental, transport, and safety conditions $^{9}$ and a negative image of older adults before the society. ${ }^{8}$ Considering that COVID-19 brought new demands to people's lives, information on the behavior adopted by older adults during this period of social isolation is scarce. Social isolation usually leaves older adults at a greater risk of developing health problems such as depression and anxiety. ${ }^{10}$

Therefore, due to their social isolation and higher risk of contracting COVID-19, studies with older adults in this critical period are scarce, especially those involving direct measures of outcomes such as muscle strength, functional capacity, blood pressure, health status, and psychological changes assessed through personal interviews. Considering the need for better understanding the impact of COVID-19 in the older adult population (in order to provide appropriate assistance during this period) and for formulating strategies to cope with the consequences of the pandemic, the purpose of this study was to analyze the changes in the daily routine and life perceptions of older adults due to the COVID-19 pandemic.

\section{METHODS}

This cross-sectional study used an online questionnaire created on the Google Forms platform; the questionnaire contained 20 questions and was applied to older adults during the isolation period brought by the COVID-19 pandemic. The online questionnaire was distributed to the participants through social networks (Facebook, Instagram, WhatsApp) and was answered between May 12 and June 11, 2020.

\section{Participants}

Participants were recruited online with the following inclusion criteria:

- aged > 60 years;

- with access to a computer or other device for answering the questionnaire.

All participants were informed in detail on the experimental procedures and possible risks and benefits of their participation and provided written informed consent by clicking the "I agree" button before advancing to the questionnaire. Initially, 418 people answered the online form. Of these, 2 participants denied participation via the consent form. Eighty participants did not meet the age criterium and 5 participants did not complete the information required by the questionnaire.

This investigation was conducted according to the Declaration of Helsinki and was approved by the local University Ethics Committee (Process 3.967.673).

\section{Questionnaire}

Each participant answered the questionnaire remotely, all questions were mandatory, and answer forms could only be submitted after all the research questions were answered. The topics included in the questionnaire were as follows:

- $\quad$ sex (male, female);

- age;

- retirement status (yes, no);

- in social isolation (yes, no);

- change in routine after social isolation (yes, no);

- leaves the house (no, only to work, only to buy essential items, whenever I need);

- practiced a physical activity before the pandemic (5-7 days a week, 3-4 days a week, 1-2 days a week, did not practice);

- continued with physical activity during the pandemic (5-7 days a week, 3-4 days a week, 1-2 days a week, stopped practicing; still not practicing);

- tiredness in the upper-body muscles when exercising for $30 \mathrm{~s}$ (no, as usual, feel more tired, feel less tired);

- tiredness in the lower-body muscles when exercising for $30 \mathrm{~s}$ (no, as usual, feel more tired, feel less tired);

- balance while walking (no change, worse, better); 
- how does it feel during brisk walking? (no difference, harder, easier);

- strength to pick up objects (same, worse, better);

- breathing when performing day-to-day tasks (same, worse, better);

- sleep quality (same, worse, better);

- daily medications (yes, no);

- number of daily medications (1 to 2 , more than 2, none);

- are you taking more medications after the pandemic? (yes, no);

- fear of contracting COVID-19 (yes, no);

- are you more concerned after the pandemic? (yes, no);

- are you more anxious after the pandemic? (yes, no).

Statistical analysis

Initially, a Kolmogorov-Smirnov test was used to assess data normality, indicating a normal distribution. A Student's $\mathrm{t}$-test for independent samples was used for comparing general characteristics of the sample (age, body mass, height, and body mass index [BMI]) between sexes (men vs women). To analyze the association between categorical variables (sex) and possible differences in sleeping habits, alcohol consumption, eating habits, and physical fitness, we used the $\chi^{2}$ test. Data were processed using SPSS (SPSS Inc., Chicago, IL, USA) version 23.0. The level of significance was set at $\mathrm{p}<0.05$.

\section{RESULTS}

In total, 338 older adults were analyzed, of which 93 were men and 238 were women $(67.92 \pm 6.73$ years, $72.81 \pm$ $12.81 \mathrm{~kg}, 163.27 \pm 8.48 \mathrm{~cm}$, and $27.47 \pm 4.54 \mathrm{~kg} / \mathrm{m}^{2}$ ). As seen in Table 1, men presented higher results regarding weight $(+12.81 \%)$ and height $(+7.82 \%)$ when compared to women $(\mathrm{p}<0.05)$. We observed that $72.37 \%$ of the older adults were between 60 and 70 years old, $63.71 \%$ were overweight (BMI $\geq 25 \mathrm{~kg} / \mathrm{m}^{2}$ ), and $76.42 \%$ were retired.

As seen in Table 2, both men and women (89.11\%) were experiencing social isolation; an association $(\mathrm{p}<0.05)$ was observed between this aspect and sex, in which women (11.42\%) experienced greater social isolation than men. Moreover, $82.21 \%$ of the older adults (men and women) reported a change in their social routines during the pandemic; women $(p<0.05)$ maintained the commitment to leave only for essential tasks more strictly when compared to men.

Regarding the physical activity profile of the older adults in our sample (Table 3), most of them were physically active before the pandemic (80.41\%); $78.62 \%$ continued with their previous physical activity despite the pandemic and the request for social isolation issued by local governments. Most older adults reported not having noticed differences in muscle fatigue regarding upper (41.42\%) and lower (45.02\%) limbs, $62.21 \%$ did not feel any difference when walking, and $76.75 \%$ did not notice alterations in their strength to pick up objects. An association $(\mathrm{p}<0.05)$ between sex and balance was observed, where men reported having maintained their balance more often when compared to women.

Regarding life habits, medication use, and behavior during the pandemic (Table 4), $77.61 \%$ of the participants were able to maintain normal breathing during day-to-day tasks and $54.71 \%$ maintained sleep quality during the pandemic. Regarding the use of medications, $84.62 \%$ of the participants took medications daily, and the pandemic did not change this behavior since $91.58 \%$ reported not starting a new medication during this period. Finally, $84 \%$ were concerned about the pandemic, $66.50 \%$ were anxious after the pandemic, and $77 \%$ were afraid of being infected by the virus.

Table 1. Characteristics of older adults during the COVID-19 pandemic $(\mathrm{N}=331)$. Data presented as means \pm standard deviations.

\begin{tabular}{l|c|c|c} 
Characteristics & $\begin{array}{c}\text { Men } \\
(\mathbf{n}=93)\end{array}$ & $\begin{array}{c}\text { Women } \\
(\mathbf{n}=238)\end{array}$ & Effect \\
\hline Age (years) & $67.92 \pm 6.11$ & $68.05 \pm 6.95$ & $\mathrm{p}=0.93$ \\
\hline Weight $(\mathrm{kg})$ & $79.31 \pm 12.81$ & $70.34 \pm 11.96$ & $\mathrm{p}<0.001$ \\
\hline Height $(\mathrm{cm})$ & $172.18 \pm 7.17$ & $159.78 \pm 6.00$ & $\mathrm{p}<0.001$ \\
\hline BMI $\left(\mathrm{kg} / \mathrm{m}^{2}\right)$ & $26.86 \pm 3.95$ & $27.68 \pm 4.78$ & $\mathrm{p}=0.13$ \\
\hline
\end{tabular}

COVID-19: coronavirus disease 2019; BMl: body mass index.

Table 2. Social behavior of older adults during the COVID-19 pandemic $(\mathrm{N}=331)$. Data presented as percentage values.

\begin{tabular}{|c|c|c|c|}
\hline Variables & $\begin{array}{c}\text { Men } \\
(n=93)\end{array}$ & $\begin{array}{l}\text { Women } \\
(n=238)\end{array}$ & Effect \\
\hline \multicolumn{4}{|l|}{ In social isolation } \\
\hline Yes & 82.81 & 91.62 & \multirow{2}{*}{$p<0.01$} \\
\hline No & 17.22 & 8.41 & \\
\hline \multicolumn{4}{|c|}{ Change in routine after social isolation } \\
\hline Yes & 82.81 & 81.98 & \multirow{2}{*}{$p=0.85$} \\
\hline No & 17.22 & 18.19 & \\
\hline \multicolumn{4}{|l|}{ Leaves the house } \\
\hline No & 22.67 & 37.88 & \multirow{4}{*}{$p<0.01$} \\
\hline Only to work & 15.12 & 3.41 & \\
\hline $\begin{array}{l}\text { Only to buy } \\
\text { essential items }\end{array}$ & 51.66 & 57.11 & \\
\hline Whenever I need & 10.83 & 1.72 & \\
\hline
\end{tabular}

COVID-19: coronavirus disease 2019. 


\section{DISCUSSION}

The aim of our study was to analyze the changes in the daily routine and life perceptions of older adults due to the COVID-19 pandemic. Our main findings were:

- a small portion of the older adults in this study were not performing social isolation, with older men being responsible for these indicators;
- the great majority of the participants practiced a physical activity before the pandemic and most of them continued to do so even during social isolation;

- the older adults in our study were managing to maintain their physical parameters (ie, muscular strength, balance, agility) during the pandemic;

Table 3. Physical behavior reported by older adults during the COVID-19 pandemic $(N=331)$.

\section{Variables}

\section{Men $(n=93)$}

Women $(n=238)$

Effect

Practiced a PA before the pandemic

\begin{tabular}{|c|c|c|c|}
\hline 5-7 days a week & 24.72 & 21.80 & \multirow{4}{*}{$p=0.81$} \\
\hline 3-4 days a week & 25.82 & 30.30 & \\
\hline 1-2 days a week & 28.01 & 29.08 & \\
\hline Did not practice & 21.55 & 18.97 & \\
\hline \multicolumn{4}{|c|}{ Continued with PA during the pandemic } \\
\hline 5-7 days a week & 23.78 & 21.80 & \multirow{5}{*}{$p=0.20$} \\
\hline 3-4 days a week & 28.07 & 40.30 & \\
\hline 1-2 days a week & 24.73 & 17.21 & \\
\hline Stopped practicing & 16.12 & 11.82 & \\
\hline Still not practicing & 7.53 & 8.88 & \\
\hline \multicolumn{4}{|c|}{ Tiredness in the upper-body muscles when exercising for $30 \mathrm{~s}$} \\
\hline No & 32.31 & 23.15 & \multirow{4}{*}{$p=0.21$} \\
\hline As usual & 40.92 & 41.60 & \\
\hline Feel more tired & 25.83 & 31.50 & \\
\hline Feel less tired & 1.14 & 3.87 & \\
\hline \multicolumn{4}{|c|}{ Tiredness in the lower-body muscles when exercising for $30 \mathrm{~s}$} \\
\hline No & 24.71 & 18.94 & \multirow{4}{*}{$p=0.08$} \\
\hline As usual & 51.62 & 42.45 & \\
\hline Feel more tired & 21.52 & 34.98 & \\
\hline Feel less tired & 2.23 & 3.87 & \\
\hline \multicolumn{4}{|l|}{ Balance while walking } \\
\hline No change & 80.66 & 72.71 & \multirow{3}{*}{$p<0.05$} \\
\hline Worse & 16.10 & 26.52 & \\
\hline Better & 3.20 & 0.82 & \\
\hline \multicolumn{4}{|c|}{ How does it feel during brisk walking? } \\
\hline No difference & 68.88 & 59.76 & \multirow{3}{*}{$p=0.20$} \\
\hline Harder & 28.03 & 38.25 & \\
\hline Easier & 3.25 & 2.15 & \\
\hline \multicolumn{4}{|c|}{ Strength to pick up objects } \\
\hline Same & 78.57 & 76.11 & \multirow{3}{*}{$p=0.37$} \\
\hline Worse & 21.50 & 21.81 & \\
\hline Better & 0 & 2.12 & \\
\hline
\end{tabular}

COVID-19: coronavirus disease; PA: physical activity. 
- participants were anxious and afraid of contracting COVID-19.

In general, an isolation period can result in inappropriate behavior, leading older adults to complicate their health. Isolation at home can lead to inadequate nutrition and sleep, moments of anxiety about what is to come, and fear of being contaminated. In addition, this forced isolation can be characterized as a detraining period, which can affect several physiological systems such as the neuromuscular, cardiovascular, and respiratory systems and their corresponding physical capacities (muscle strength and power, resistance, flexibility).

Maintaining adequate levels of physical activity can assist in different health-related outcomes. Even though $89.11 \%$ of the participants admitted experiencing social isolation,
$78.62 \%$ reported having continued their regular physical activities; therefore, most of the older adults in our sample who were in social isolation continued with regular physical activity. This is important since physical activity has a positive impact on health and quality of life, reducing the risks of functional and cognitive difficulties, falls, fractures, depression, geriatric syndromes, and hospitalization (which must be avoided during the pandemic), consequently reducing mortality in the older adult. ${ }^{11}$

Therefore, we inferred that many older adults knew the benefits of regular physical activity and decided to continue with it. A similar situation was reported in a study by Goethals et al. ${ }^{12}$, in which French older adults expressed the need to continue performing physical activities at home. This information was added to the older adults' own perceptions, where

Table 4. Life habits, medication use, and behavior reported by older adults during the COVID-19 pandemic ( $\mathrm{N}=331$ ).

\begin{tabular}{|c|c|c|c|}
\hline Variables & Men $(n=93)$ & Women $(n=238)$ & Effect \\
\hline \multicolumn{4}{|c|}{ Breathing when performing day-to-day tasks } \\
\hline Same & 83.91 & 75.21 & \multirow{3}{*}{$p=0.12$} \\
\hline Worse & 16.12 & 22.32 & \\
\hline Better & 0 & 02.53 & \\
\hline \multicolumn{4}{|l|}{ Sleep quality } \\
\hline Same & 55.91 & 54.23 & \multirow{3}{*}{$p=0.46$} \\
\hline Worse & 30.12 & 35.78 & \\
\hline Better & 14.00 & 10.17 & \\
\hline \multicolumn{4}{|c|}{ Daily medications } \\
\hline Yes & 87.10 & 83.62 & \multirow{2}{*}{$p=0.43$} \\
\hline No & 12.91 & 16.47 & \\
\hline \multicolumn{4}{|c|}{ Number of daily medications } \\
\hline 1 to 2 & 42.00 & 36.19 & \multirow{2}{*}{$p=0.38$} \\
\hline 3 or more & 58.15 & 63.91 & \\
\hline \multicolumn{4}{|c|}{ Are you taking more medications after the pandemic? } \\
\hline Yes & 05.47 & 09.78 & \multirow{2}{*}{$p=0.21$} \\
\hline No & 94.67 & 90.35 & \\
\hline \multicolumn{4}{|c|}{ Fear of contracting COVID-19 } \\
\hline Yes & 76.38 & 77.31 & \multirow{2}{*}{$p=0.85$} \\
\hline No & 23.77 & 22.72 & \\
\hline \multicolumn{4}{|c|}{ Are you more concerned after the pandemic? } \\
\hline Yes & 82.81 & 84.52 & \multirow{2}{*}{$p=0.71$} \\
\hline No & 17.23 & 15.53 & \\
\hline \multicolumn{4}{|c|}{ Are you more anxious after the pandemic? } \\
\hline Yes & 61.31 & 68.53 & \multirow{2}{*}{$p=0.21$} \\
\hline No & 38.72 & 31.53 & \\
\hline
\end{tabular}

COVID-19: coronavirus disease. 
they had not noticed changes in muscular strength, ability to walk, and balance during the isolation period.

However, important aspects that need to be observed are the health factors of the older adults interviewed in this study. According to the literature, ${ }^{13,14}$ some factors can facilitate COVID-19 transmission and health complications in people who are contaminated by the virus. In this study, $63.71 \%$ of the older adults were overweight and using medications (84.62\%), indicating that they had previous pathologies. In addition, a small portion of the participants (especially older men) still worked, which forced them to stay out of their homes for a long time. Literature data ${ }^{15}$ have shown that older adults who are overweight and have comorbidities are more likely to have complications from COVID-19.

An important point to be observed in older adults is the fear of contracting COVID-19. Both men and women were afraid of contracting the disease (77.00\%). This was well observed by the anxiety parameter, which showed that $65.50 \%$ are more anxious after the pandemic. This fear is probably due, in addition to other factors, to the fact that age is the most important factor that decreases the chances of surviving COVID-19, especially after 60 years of age. ${ }^{16}$

In older adults, anxiety disorders usually last for years and are mostly associated with depression, serious illnesses, or adverse drug reactions. ${ }^{17}$ Anxiety disorders are often difficult to treat because many older adults with anxiety end up with other concomitant mental disorders such as hypochondria due to the accumulation of different life events and functional declines. Other aspects that complicate alcoholism treatment are anxiety, depression, and insomnia. ${ }^{18} \mathrm{~A}$ study by Lei et al. ${ }^{19}$ found an increase in the prevalence of anxiety and depression in Chinese participants of different age groups, but mainly in older adults. Duan and $\mathrm{Zhu}^{20}$ also noted an increase in psychological problems during the pandemic, including stress, anxiety, and depression.

Some limitations of our study need to be addressed. We employed an online questionnaire and requested only older adults to answer it, but the actual age of the participants was out of our control. We did not employ any direct and objective measures related to their health status such as muscle strength, body composition, or blood pressure. However, this was not performed due to the social isolation imposed by the pandemic. Our responders only included people who had access to the internet and who could read. Finally, our sample consisted of older adults from southern Brazil, which hampers the possibility of extrapolating the results to other regions of the country. Future investigations need to analyze the real effects of the post-pandemic period on several health aspects in order to provide specific strategies to deal with the consequences of this tragic moment, especially in older adults.

We concluded that there was a higher prevalence of older women that experienced higher levels of social isolation and a higher prevalence of older men who maintained their perception of balance during the social isolation period. These results will enable health professionals to better understand how the pandemic is affecting older adults' lives and to provide a more specific approach when helping this population go through this critical period, respecting the differences observed between sexes in their behavior regarding this moment.

\section{CONFLICTS OF INTEREST}

The authors declare no conflicts of interest.

\section{FUNDING}

This research did not receive any specific grant from funding agencies in the public, commercial, or not-for-profit sectors.

\section{AUTHORS' CONTRIBUTION}

RGF: conceptualization. DVO: formal analysis. AG: conceptualization. HSF: visualization. FRG: visualization. LF: conceptualization. JRANJ: formal analysis. FLCP: conceptualization. JLM: writing — review \& editing. MAN: conceptualization, supervision, writing — review \& editing.

\section{REFERENCES}

1. Guo YR, Cao QD, Hong ZS, Tan YY, Chen SD, Jin HJ, et al. The origin, transmission and clinical therapies on coronavirus disease 2019 (COVID-19) outbreak - an update on the status. Mil Med Res. 2020;7(1):11. https://doi.org/10.1186/s40779-020-00240-0

2. Chen P, Mao L, Nassis GP, Harmer P, Ainsworth BE, Li F. Coronavirus disease (COVID-19): The need to maintain regular physical activity while taking precautions. J Sport Health Sci. 2020;9(2):103-4. https:// doi.org/10.1016/j.jshs.2020.02.001
3. Lloyd-Sherlock P, Ebrahim S, Geffen L, McKee M. Bearing the brunt of covid-19: older people in low and middle income countries. BMJ. 2020;368:m1052. https://doi.org/10.1136/bmj. m1052

4. Brasil. Ministério da Saúde. Boletim Epidemiológico. Available from: https:/portalarquivos2.saude.gov.br/images/pdf/2020/fevereiro/13/ Boletim-epidemiologico-COEcorona-SVS-13fev20.pdf. Accessed in Oct 31, 2020 
5. Goodell JW. COVID-19 and finance: Agendas for future research. Financ Res Lett. 2020;35:101512. https://doi.org/10.1016/j. frl.2020.101512

6. Nicola M, Alsafi Z, Sohrabi C, Kerwan A, Al-Jabir A, losifidis C, et al. The socio-economic implications of the coronavirus pandemic (COVID-19): A review. Int J Surg. 2020;78:185-93. https://doi. org/10.1016/j.ijsu.2020.04.018

7. Hirvensalo M, Lintunen T. Life-course perspective for physical activity and sports participation. Eur Rev Aging Phys Act. 2011;8:13-22. https://doi.org/10.1007/s11556-010-0076-3

8. Moschny A, Platen P, Klaassen-Mielke R, Trampisch U, Hinrichs T. Barriers to physical activity in older adults in Germany: a crosssectional study. Int J Behav Nutr Phys Act. 2011;8:121. https://doi. org/10.1186/1479-5868-8-121

9. Cassou AC, Fermino R, Rodriguez Añez CR, Santos MS, Domingues MR, Reis RS. Barriers to physical activity among Brazilian elderly women from different socioeconomic status: a focus-group study. J Phys Act Health. 2011;8(1):126-32. https://doi.org/10.1123/ jpah.8.1.126

10. Oliveira R, Santa-Marinha C, Leão R, Monteiro D, Bento T, Santos Rocha $\mathrm{R}$, et al. Exercise training programs and detraining in older women. J Hum Sport Exerc. 2017;12(1):142-55. https://doi. org/10.14198/jhse.2017.121.12

11. Sepúlveda-Loyola W, Rodríguez-Sánchez I, Pérez-Rodríguez P, Ganz F, Torralba R, Oliveira DV, et al. Impact of Social Isolation Due to COVID-19 on Health in Older People: Mental and Physical Effects and Recommendations. J Nutr Health Aging. 2020;1-10. https://doi. org/10.1007/s12603-020-1469-2

12. Goethals L, Barth N, Guyot J, Hupin D, Celarier T, Bongue B. Impact of Home Quarantine on Physical Activity Among Older Adults Living at Home During the COVID-19 Pandemic: Qualitative Interview Study. JMIR Aging. 2020;3(1):e19007. https://doi.org/10.2196/19007
13. Shahid Z, Kalayanamitra R, McClafferty B, Kepko D, Ramgobin D, Patel R, et al. COVID-19 and Older Adults: What We Know. J Am Geriatr Soc. 2020;68(5):926-9. https://doi.org/10.1111/ jgs.16472

14. Nikolich-Zugich J, Knox KS, Rios CT, Natt B, Bhattacharya D, Fain MJ. SARS-CoV-2 and COVID-19 in older adults: what we may expect regarding pathogenesis, immune responses, and outcomes. Geroscience. 2020;42(2):505-14. https://doi.org/10.1007/s11357020-00186-0

15. Nanda A, Vura NVRK, Gravenstein S. COVID-19 in older adults Aging Clin Exp Res. 2020;32(7):1 199-202. https://doi.org/10.1007/ s40520-020-01581-5

16. Daoust JF. Elderly people and responses to COVID-19 in 27 Countries. PLoS One. 2020;15(7):e0235590. https://doi.org/10.1371/journal. pone.0235590

17. Meuldijk D, Wuthrich VM. Stepped-care treatment of anxiety and depression in older adults: A narrative review. Aust J Rural Health. 2019;27(4):275-80. https://doi.org/10.1111/ajr.12524

18. Heesterbeek TJ, van der Aa HPA, van Rens GHMB, Twisk JWR, van Nispen RMA. The incidence and predictors of depressive and anxiety symptoms in older adults with vision impairment: a longitudinal prospective cohort study. Ophthalmic Physiol Opt. 2017;37(4):38598. https://doi.org/10.1111/opo.12388

19. Lei L, Huang X, Zhang S, Yang J, Yang L, Xu M. Comparison of Prevalence and Associated Factors of Anxiety and Depression Among People Affected by versus People Unaffected by Quarantine During the COVID-19 Epidemic in Southwestern China. Med Sci Monit. 2020;26:e924609. https://doi.org/10.12659/ MSM.924609

20. Duan L, Zhu G. Psychological interventions for people affected by the COVID-19 epidemic. Lancet Psychiatry. 2020;7(4):300-2. https:// doi.org/10.1016/S2215-0366(20)30073-0 